\title{
Experimental Helicobacter marmotae infection in A/J mice causes enterohepatic disease
}

Correspondence

James G. Fox

jgfox@mit.edu

Received 15 March 2010

Accepted 8 July 2010

\author{
Mary M. Patterson, Arlin B. Rogerst and James G. Fox \\ Division of Comparative Medicine, Massachusetts Institute of Technology, \\ 77 Massachusetts Avenue, Building 16-825, Cambridge, MA 02139, USA
}

\section{INTRODUCTION}

Although the impact that gastric helicobacter species, particularly Helicobacter pylori, have had on our current understanding of gastrointestinal disease cannot be overestimated, the ability of enterohepatic helicobacters to cause disease is also being examined. Naturally occurring enterohepatic species have been found associated with pathological conditions in humans and animals on numerous occasions. For example, Helicobacter cinaedi was isolated from bacteraemic humans and from the liver of a rhesus macaque with hepatitis and idiopathic colitis (Cimolai et al., 1987; Fox et al., 2001; Orlicek et al., 1993; Vandamme et al., 1990). The liver of a puppy with multifocal hepatitis was colonized with Helicobacter canis, and the organism was cultured from diarrhoeic faeces of a child and bacteraemic humans (Burnens et al., 1993; Fox et al., 1996a). 'Helicobacter rappini' (now classified in the Helicobacter bilis taxon) was recovered from ovine fetuses

tPresent address: Campus Box 7431, University of North Carolina, Chapel Hill, NC 27599-7431, USA.

Abbreviations: $\mathrm{H}$ and $\mathrm{E}$, haematoxylin and eosin; p.i., post-inoculation; WHV, woodchuck hepatitis virus. with hepatic necrosis, and has been described in association with gastroenteritis and bacteraemia in humans (Archer et al., 1988; Kirkbride et al., 1985; Weir et al., 1999). A novel helicobacter belonging to the $H$. bilis taxon has been identified in the livers and colons of hamsters with hepatobiliary and intestinal disease (Fox et al., 2009). Similarly, the inflamed livers of mice were shown to be naturally infected with $H$. bilis (Fox et al., 1995, 2004). Aged male A/JCr mice infected with Helicobacter hepaticus have an increased incidence of hepatomas and hepatocellular carcinomas, whilst infected immunodeficient mice not only develop chronic hepatitis but also inflammatory bowel disease and colon cancer (Erdman et al., 2003, 2009; Fox et al., 1996b; Li et al., 1998; Ward et al., 1996). Other studies have also involved $H$. hepaticus inoculation into helicobacter-free mice, with the result of liver lesions or inflammatory bowel disease depending on mouse strain and experimental design (Cahill et al., 1997; Fox et al., 1996b, c, 2010; Whary et al., 1998).

A novel enterohepatic helicobacter named Helicobacter marmotae has been detected, by culture and PCR, from the inflamed livers of Eastern woodchucks (Marmota monax), some of which were infected with woodchuck hepatitis 
virus (WHV), and from the faeces of commercially raised cats (Fox et al., 2002). For years, the woodchuck-WHV system has been used as a model of hepatitis B virus infection in humans (Menne \& Cote, 2007; Tennant \& Gerin, 2001). Its popularity is sustained because woodchucks with chronic WHV infection develop hepatocellular carcinomas and hepatitis at a high frequency, with lesions similar to those in humans with hepatitis B virus. As nine out of ten WHV-infected woodchucks that had hepatic tumours and all WHV-negative woodchucks that had inflamed livers were either culture or PCR positive for $H$. marmotae, the question arises as to whether chronic inflammation associated with the presence of $H$. marmotae can act as a tumour promoter. Besides the gastric helicobacters $H$. pylori and Helicobacter mustelae, precedence for helicobacter involvement in carcinogenesis has been demonstrated with $H$. hepaticus in $\mathrm{A} / \mathrm{J}, \mathrm{AxB}, \mathrm{B} 6 \mathrm{C} 3 \mathrm{~F} 1$, AB6F1 and B6Af1 mice (Fox \& Wang, 2000; Fox et al., 1997; Garcia et al., 2008; Hailey et al., 1998; Ihrig et al., 1999; Ward et al., 1994). In the present study, male and female $\mathrm{A} / \mathrm{J}$ mice were inoculated with the type strain of $H$. marmotae to evaluate features of colonization, concomitant pathology and serological response. Achieving H. marmotae colonization in mice for future experiments has obvious advantages over using the original woodchuck host, such as a shorter generation time and the availability of inbred and genetically engineered strains.

\section{METHODS}

Animals. Thirty-two male and thirty-two female A/J mice of 4-6 weeks of age received from The Jackson Laboratory were helicobacterfree and free of antibody to specific murine viruses. During the study, four same-sexed mice per cage were housed in microisolator cages within an Association for Assessment and Accreditation of Laboratory Animal Care-accredited facility. All animal manipulations were preapproved by the Committee on Animal Care of the Massachusetts Institute of Technology.

Bacterial inoculation and study design. H. marmotae (ATCC BAA-546) was grown under microaerobic conditions at $37{ }^{\circ} \mathrm{C}$ in sterile Brucella broth (Difco Laboratories) containing $5 \%$ fetal calf serum (Summit Biotechnology). After $48 \mathrm{~h}$ of incubation on a rotary shaker, the culture was centrifuged at $9300 \mathrm{~g}$ for $20 \mathrm{~min}$ at $4{ }^{\circ} \mathrm{C}$. Phase microscopy and Gram staining were used to assure the purity of the culture. The bacterial pellet was resuspended in sterile PBS to a concentration of approximately $10^{7}$ organisms $\mathrm{ml}^{-1}$ based on spectrophotometric examination. Using a previously published inoculation strategy, experimental mice (24 males, 24 females) received $0.2 \mathrm{ml}$ inoculum by intraperitoneal injection, whilst control mice ( 8 males, 8 females) were given $0.2 \mathrm{ml}$ sterile PBS (McCathey et al., 1999; Shomer et al., 2001). One mouse from each cage (total of two control and six experimental mice of each sex) was necropsied at 6 and 12 months after dosing; necropsies on the remaining mice were performed when the study was concluded at 18 months postinoculation (p.i.).

Reisolation of $\boldsymbol{H}$. marmotae from faeces, caeca and livers. Pooled faeces (three to four pellets) from each cage of mice were collected at 1, 3, 6 and 9 months p.i. and placed in $500 \mu \mathrm{l} \mathrm{Brucella}$ broth with $30 \%$ glycerol. At necropsy, liver samples were excised aseptically and the caeca were gently scraped to remove luminal contents prior to storage in the Brucella broth/glycerol freezer medium. Faecal and tissue samples were frozen at $-70{ }^{\circ} \mathrm{C}$ until further processing. To culture for $\mathrm{H}$. marmotae, the sample material was homogenized in the freezer medium and the supernatant passed through a $0.45 \mu \mathrm{m}$ filter. Filtered aliquots were placed on blood agar plates containing cefoperazone, vancomycin, and amphotericin B (CVA medium; Remel). The plates were incubated for up to 2 weeks in a microaerobic environment at $37{ }^{\circ} \mathrm{C}$.

Analysis of faecal, caecal and hepatic DNA by PCR. Faecal pellets were also collected from each cage at 1, 3, 6 and 9 months p.i. to assess for the presence of helicobacter DNA. Three to four faecal pellets were homogenized in $1 \mathrm{ml}$ PBS and DNA was extracted from the supernatant solution following the kit manufacturer's instructions (QIAamp DNA mini kit and QIAamp DNA blood mini kit; Qiagen). DNA from caecal and liver tissue was obtained using a High Pure PCR template preparation kit (Roche Molecular Biochemicals). PCR was performed using either all-helicobacter primers (C97 and C98) or primers designed specifically for $H$. marmotae (Fox et al., 1998, 2002). An aliquot of the PCR product was electrophoresed through a $6 \%$ Visigel separation matrix (Stratagene) followed by ethidium bromide staining and visualization.

Histology. Caecal and liver tissues were fixed in $10 \%$ neutral buffered formalin, sectioned at $5 \mu \mathrm{m}$ and stained with haematoxylin and eosin ( $\mathrm{H}$ and $\mathrm{E})$ for histopathological analysis. In a blinded manner, ileocaecal junction and liver morphology were evaluated by criteria that included inflammation, hyperplasia and necrosis. Lesions were scored on a scale of $0-4$ : 0 , none; 1 , minimal to mild; 2 , mild to moderate; 3 , moderate to severe; 4 , diffusely severe. A Warthin-Starry silver stain was used for visual detection of $H$. marmotae.

ELISA for anti-H. marmotae IgG in serum. An outer-membrane antigen preparation of $H$. marmotae was obtained using methods previously described for $H$. hepaticus antigen (Whary et al., 1998). A Brucella broth culture of the bacteria (see above) was washed in PBS three times. Following microscopic examination for purity, the bacterial pellet was resuspended in $4 \mathrm{ml} 1 \% \mathrm{~N}$-octyl- $\beta$-glucopyranoside for $30 \mathrm{~min}$ at room temperature. Ultracentrifugation at $100000 \mathrm{~g}$ for $1 \mathrm{~h}$ was used to remove insoluble material. After dialysis against PBS at $4{ }^{\circ} \mathrm{C}$ for $24 \mathrm{~h}$, the supernatant protein concentration was determined. Serum was collected from each mouse at necropsy and stored at $-20{ }^{\circ} \mathrm{C}$. For serum IgG determination, 96-well plates were coated with $100 \mu \mathrm{l}$. marmotae outer-membrane antigen preparation $\left(1 \mu \mathrm{g} \mathrm{ml}^{-1}\right)$ per well in carbonate buffer ( $\left.\mathrm{pH} 9.6\right)$ overnight at $4{ }^{\circ} \mathrm{C}$. Biotinylated goat anti-mouse IgG was used as a secondary antibody. Incubation with ExtrAvidin peroxidase (Sigma-Aldrich) was followed by 2,2'-azino-bis(3-ethylbenzthiazoline-6-sulfonic acid) for colour development. Serum samples were diluted $1: 100$, and IgG results were reported as mean $A_{405}$ values, with all samples run in duplicate.

Statistical analysis. Mice were grouped by inoculation/colonization status, time point p.i. and gender. For comparison of control and experimental groups, a Mann-Whitney non-parametric test was applied. Serological data were assessed by analysis of variance of the differences between the groups.

\section{RESULTS}

\section{Colonization of $\boldsymbol{H}$. marmotae in $\mathrm{A} / \mathrm{J}$ mice}

Based on cultures of pooled faeces, five out of six cages housing inoculated male $\mathrm{A} / \mathrm{J}$ mice had evidence of 
H. marmotae colonization at 1 month p.i., whereas none of the cages containing inoculated female mice had positive faecal cultures (Table 1). However, by 3 months p.i., females inoculated with $H$. marmotae housed in two of the six cages had positive faecal cultures. For the later time points at 6 and 9 months p.i. when pooled faeces were assessed, the same experimental cages of male (five out of six) and female (two out of six) A/J mice remained persistently colonized with $H$. marmotae. Faecal cultures from the mock-infected mice cages were always negative for $H$. marmotae. When faeces collected from cages at 1 month p.i. were examined by PCR, all of the cages containing male experimental mice (six out of six) were positive. All other post-dosing PCR results on pooled faeces concurred with the culture results.

Caecal and liver cultures from control mice were consistently negative for $H$. marmotae. At 6, 12 and 18 months p.i. when necropsies were performed (Table 1), the caeca of experimental male and female mice taken from cages that had positive pooled faecal cultures were positive for $H$. marmotae by culture. There were no positive $H$. marmotae caecal cultures from experimental mice that came from cages where detectable $H$. marmotae infection was never established, as demonstrated by negative pooled faecal cultures and PCR. H. marmotae was cultured from the liver samples of one experimental male $\mathrm{A} / \mathrm{J}$ mouse necropsied at 12 months p.i. and one male mouse at 18 months p.i.; these mice also had positive caecal cultures.

A subset of tissue samples chosen at random was analysed by PCR using $H$. marmotae-specific primers. The data (not shown) confirmed the tissue culture results in that the

Table 1. Culture and $P C R$ results for $A / J$ mice dosed with H. marmotae

\begin{tabular}{|lcccccc|}
\hline Experiment & \multicolumn{5}{c|}{ Time p.i. (months) } \\
\cline { 2 - 7 } & $\mathbf{1}$ & $\mathbf{3}$ & $\mathbf{6}$ & $\mathbf{9}$ & $\mathbf{1 2}$ & $\mathbf{1 8}$ \\
\hline $\begin{array}{l}\text { Male A/J mice } \\
\begin{array}{l}\text { Pooled faeces } \\
\text { cultures }\end{array}\end{array}$ & $5 / 6$ & $5 / 6$ & $5 / 6$ & $5 / 6$ & $\mathrm{ND}$ & $\mathrm{ND}$ \\
$\begin{array}{l}\text { Pooled faeces } \\
\quad \text { PCR }\end{array}$ & $6 / 6$ & $5 / 6$ & $5 / 6$ & $5 / 6$ & $\mathrm{ND}$ & $\mathrm{ND}$ \\
$\begin{array}{l}\text { Caecal culture } \dagger \\
\text { Liver culture } \dagger\end{array}$ & $\mathrm{ND}$ & $\mathrm{ND}$ & $5 / 6$ & $\mathrm{ND}$ & $5 / 6$ & $8 / 10$ \\
$\begin{array}{l}\text { Female A/J mice } \\
\text { Pooled faeces }\end{array}$ & $0 / 6$ & $2 / 6$ & $2 / 6$ & $2 / 6$ & $\mathrm{ND}$ & $\mathrm{ND}$ \\
$\quad$ cultures \\
$\begin{array}{l}\text { Pooled faeces } \\
\quad \text { PCR }\end{array}$ & $0 / 6$ & $2 / 6$ & $2 / 6$ & $2 / 6$ & $\mathrm{ND}$ & $\mathrm{ND}$ \\
$\begin{array}{l}\text { Caecal culture } \dagger \\
\text { Liver culture } \dagger\end{array}$ & $\mathrm{ND}$ & $\mathrm{ND}$ & $2 / 6$ & $\mathrm{ND}$ & $2 / 6$ & $2 / 7$ \\
& $\mathrm{ND}$ & $\mathrm{ND}$ & $0 / 6$ & $\mathrm{ND}$ & $0 / 6$ & $0 / 7$ \\
\hline
\end{tabular}

ND, Not done.

${ }^{\star}$ Number of positive cages/total number of cages sampled.

$\uparrow$ Number of positive mice/total number of mice in group. caeca and livers of dosed but uninfected experimental mice were negative for $H$. marmotae DNA at the three necropsy time points. Also, of the infected experimental mice, only the livers from which $H$. marmotae was cultured were positive by the PCR method.

\section{Histopathological evaluation}

Mice infected with $H$. marmotae developed typhlocolitis and hepatitis. Inflammation in the large bowel was most severe at the caecocolic junction and proximal colon. In more severely affected animals, the caecocolic inflammation extended midway to the caecal apex and through the mid-distal colon. Inflammatory cells were composed primarily of lymphocytes, with fewer plasma cells and macrophages. Neutrophils comprised a minor percentage of some inflammatory infiltrates, and rare tissue sections contained eosinophils. Necrosis and hyperplasia were not important histological features in the large bowel. Caecocolic inflammation and oedema were limited to the lamina propria in most instances, although extension to the submucosa was prominent in more severe cases (Fig. 1). Multifocal hepatic inflammation was centred on portal triads, but occasional foci were random in distribution (Fig. 2). Inflammatory populations in liver samples were composed chiefly of mononuclear cells (Fig. 3); however, more severe cases had evidence of chronic periportal and random hepatitis with mixtures of mononuclear and polymorphonuclear cells. Bacteria with morphology consistent with $H$. marmotae were visible in the Warthin-Starry-stained liver sections of mice with positive liver cultures (Fig. 4). Infected mice with the most severe liver lesions exhibited mild to moderate intralesional hepatocellular apoptosis and/or necrosis with little evidence of hyperplasia.

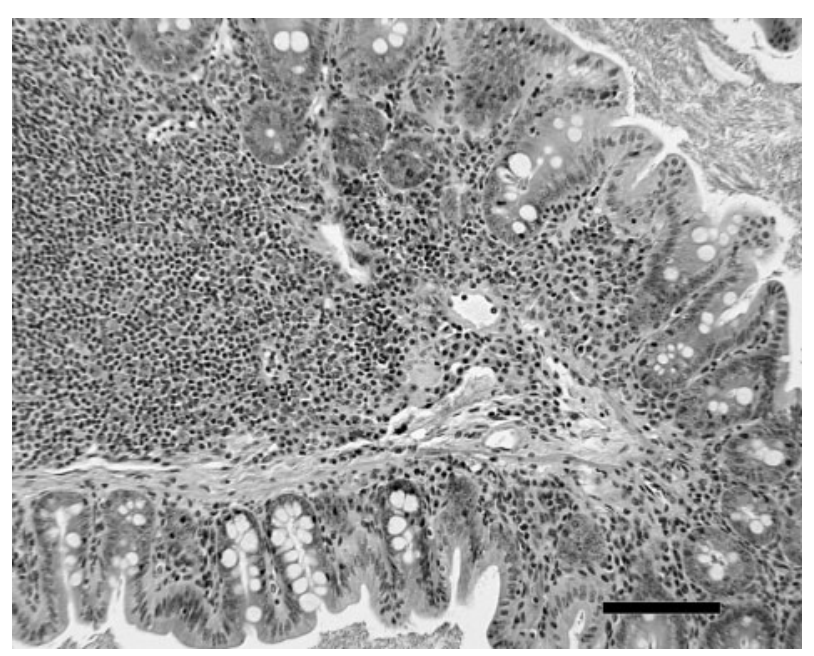

Fig. 1. Chronic typhlitis in the caecum of a male $A / J$ mouse infected with $H$. marmotae for 12 months. $\mathrm{H}$ and $\mathrm{E}$ stained. Bar, $250 \mu \mathrm{m}$. 


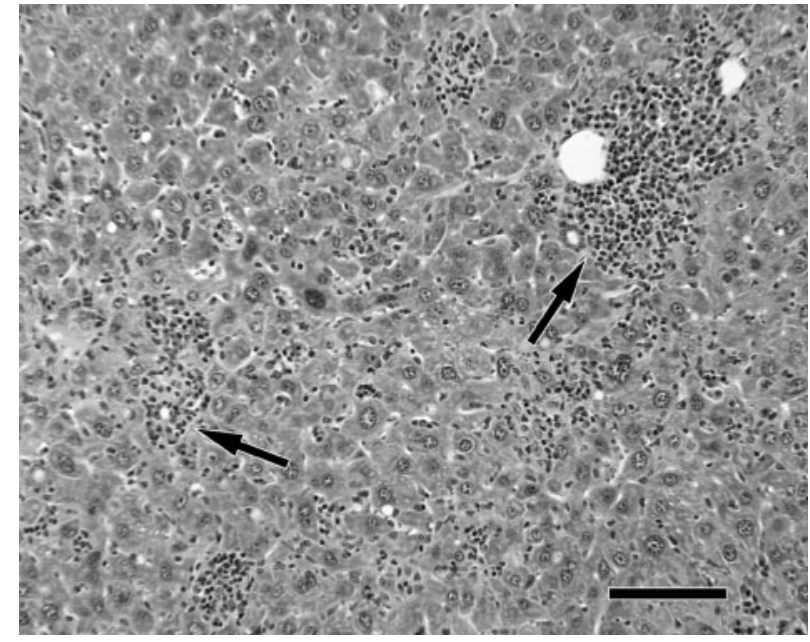

Fig. 2. Periportal hepatitis (indicated by arrows) and random hepatitis in a male $A / J$ mouse infected with $H$. marmotae for 12 months. $\mathrm{H}$ and $\mathrm{E}$ stained. Bar, $250 \mu \mathrm{m}$.

Lesion scores were higher in $H$. marmotae experimentally infected mice than in mock-dosed controls (Table 2); experimental mice that were never colonized by $H$. marmotae were not included in the statistical analyses. Regarding caecal and hepatic inflammation there was no significant difference attributable to gender, except at the 18 month time point when some control female mice had developed low-grade hepatitis (median lesion score of 1.5 versus 0.5 for the control male mice at 18 months p.i.) commonly noted in aged inbred mice. Hence, the data on caecal/proximal colon and hepatic lesion scores from male and female mice were combined. At 6, 12 and 18 months p.i., statistically higher $(P<0.05)$ mean inflammation

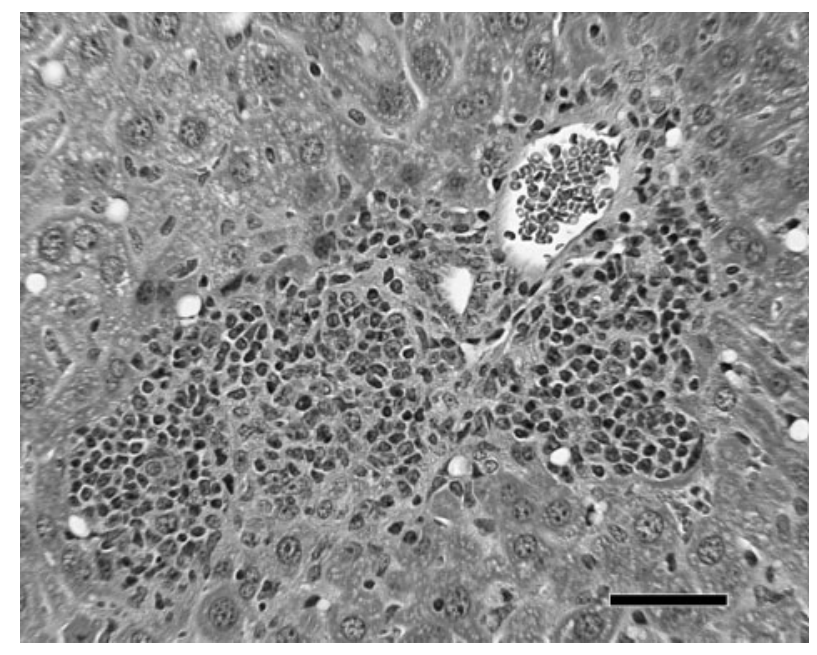

Fig. 3. Higher magnification view of primarily mononuclear cell infiltrate in the hepatic portal region. $\mathrm{H}$ and $\mathrm{E}$ stained. Bar, $125 \mu \mathrm{m}$.

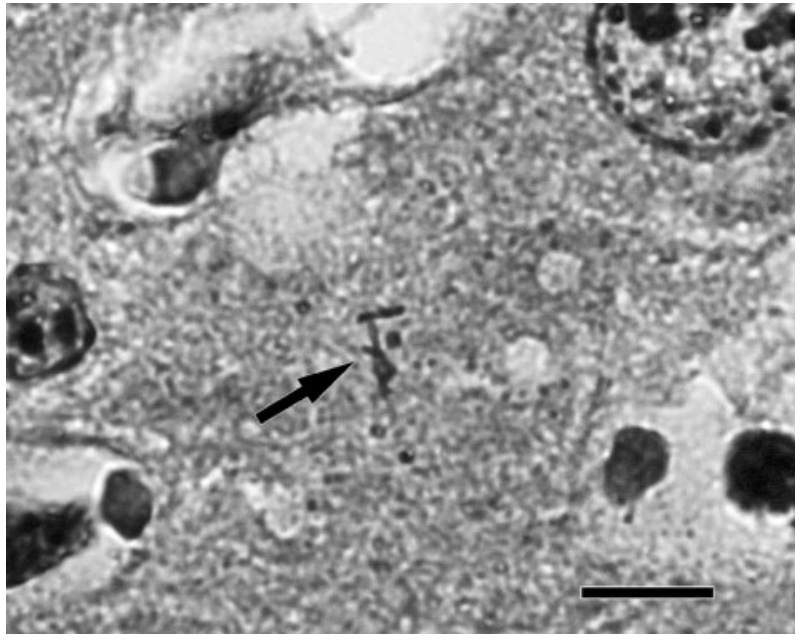

Fig. 4. Three spiral argyrophilic $H$. marmotae bacteria (indicated by an arrow) in a hepatic canaliculus from a culture-positive liver. Warthin-Starry stained. Bar, $10 \mu \mathrm{m}$.

scores for the caecum and proximal colon were observed in the colonized experimental mice compared with the control mice. Differences in hepatic inflammation were significant at 6 and 12 months p.i. between the two groups $(P<0.05)$.

\section{Serum IgG responses to $\boldsymbol{H}$. marmotae}

Mice experimentally dosed with $H$. marmotae, whether or not colonization occurred, generated an IgG response that was statistically different $(P<0.05)$ from the titres of the mock-inoculated group (Fig. 5). The IgG levels in the experimental groups did not change appreciably between the 6 and 18 month p.i. time points.

\section{DISCUSSION}

Intraperitoneal inoculation of $H$. marmotae and subsequent colonization by the bacterium resulted in statistically significant typhlocolitis in A/J mice at 6,12 and 18 months p.i. compared with mock-dosed mice, and animals with positive caecal cultures had more severe inflammation. These results are similar to those reported when a urease-negative novel Helicobacter sp. was inoculated intraperitoneally in A/J mice (Shomer et al., 2001); likewise, $H$. hepaticus caused typhlitis in $\mathrm{A} / \mathrm{J}$ mice when given by oral gavage (Whary et al., 1998). Findings of lower-bowel pathology in immunocompetent mice caused by Helicobacter species are important for modelling inflammatory bowel disease in humans. In the present study, significant hepatitis was also related to H. marmotae infection at 6 and 12 months p.i. Hepatic lesions at 18 months p.i. remained higher in the experimental mice, but these were not statistically significant because spontaneous focal, mild hepatitis had developed in selected control mice, a lesion 
Table 2. Caecal/proximal colon and hepatic lesion scores in $H$. marmotae-colonized $A / J$ mice and controls

Scores are given as the median (range).

\begin{tabular}{|lcc|}
\hline Time p.i. & Control mice & Experimental infected mice \\
\hline $\mathbf{6}$ months & & \\
Caecal/proximal colon scores & $0.25(0-0.5)$ & $2.0(1.0-2.5) \dagger$ \\
Hepatic scores & $0(0)$ & $1.0(0-2.0) \dagger$ \\
No. of mice & Two males, two females & Five males, two females \\
$\mathbf{1 2}$ months & $0.5(0.5)$ & $2.5(2.0-3.0) \dagger$ \\
Caecal/proximal lesion scores & $0.25(0-0.5)$ & $1.0(0.5-3.0) \dagger$ \\
Hepatic scores & Two males, two females & Five males, two females \\
No. of mice & $1.0(0.5-1.0)$ & $2.25(1.5-3.0) \dagger$ \\
$\mathbf{1 8}$ months & $0.5(0.5-1.5)$ & $1.0(0-3.5)$ \\
Caecal/proximal lesion scores & Three males, two females & Eight males, two females \\
Hepatic scores & \\
No. of mice & & \\
\end{tabular}

* Mice euthanized early due to health concerns were added into the analysis with data for the closest time point if cultures and complete necropsies were performed.

$\dagger P<0.05$ compared with value for control mice (Mann-Whitney test).

commonly observed in aged inbred mice (Sundberg et al., 1997). Overall, the pathology that developed was inflammatory in nature, without the hyperplasia and necrosis that characterizes infection in mice with $H$. hepaticus (Fox et al., 1996c; Ward et al., 1994), except for severely affected experimental mice with hepatitis.

Another difference not observed in $H$. hepaticus infection in $\mathrm{A} / \mathrm{J}$ mice was that $H$. marmotae-associated lesions did not progress dramatically from 6 to 18 months. Pathogenic mechanisms may be different in these two urease-positive helicobacters, although $H$. marmotae, like $H$. hepaticus, Helicobacter pullorum, H. bilis, H. cinaedi and Campylobacter jejuni, expresses cytolethal distending toxin, which causes cell-cycle arrest (Chien et al., 2000). The presence of the toxin in $H$. hepaticus and $H$. cinaedi promotes

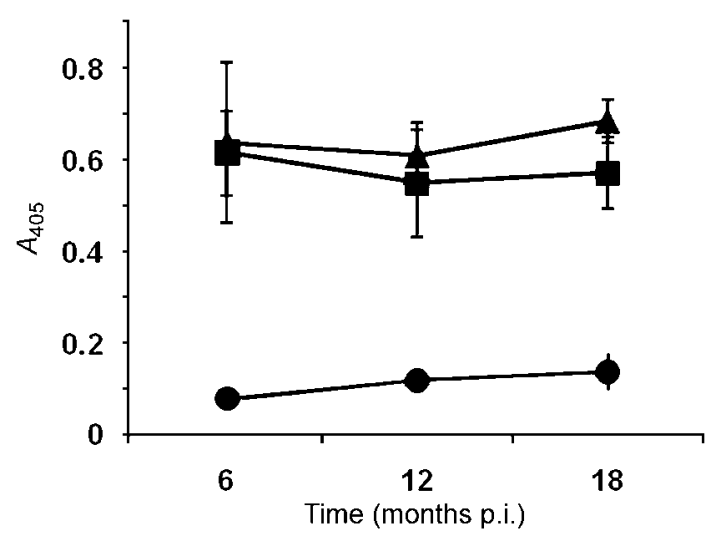

Fig. 5. IgG response to $H$. marmotae in the sera of infected $(\boldsymbol{\Delta}), H$. marmotae-inoculated but uninfected $(\boldsymbol{\square})$ and control $(\boldsymbol{O}) \mathrm{A} / \mathrm{J}$ mice. helicobacter-associated typhlocolitis in interleukin-10-deficient mice (Shen et al., 2009; Young et al., 2004). Whether this toxin plays a similar role in $\mathrm{A} / \mathrm{J}$ mice with $H$. marmotae-induced gastrointestinal disease requires further studies.

Once the mice in a given cage were positive by faecal culture for $H$. marmotae, all of the animals in that cage became persistently colonized as shown by caecal cultures at necropsy. However, whilst the majority of male A/J mice (five out of six cages) became infected, only one-third of the females housed in cages were successfully colonized by the organism. It also took longer for colonization to be detected in the female mice, as at 1 month p.i. all of the cultures and PCR analyses of faeces pooled from female cages were negative for $H$. marmotae. In addition, the two liver samples that were culture positive for $H$. marmotae, presumably by intestinal translocation, occurred in male mice. Sporadic liver colonization, despite persistent colonization of the lower bowel, is also characteristic of $H$. hepaticus infection in A/J mice (Fox et al., 1996b). Even though the overall lesion severity indices were similar in $H$. marmotae-colonized male and female mice, the highest hepatitis scores assigned during the study belonged to the two male mice that had livers from which the organism was recovered by culture. Female A/J mice may be able to limit bacterial colonization more effectively than male mice, perhaps by immune or hormonal mechanisms. The same gender bias has also been documented in $\mathrm{A} / \mathrm{J}$ and $\mathrm{AXB}$ mice infected with $H$. hepaticus (Fox et al., 1996b; Ihrig et al., 1999; Ward et al., 1994).

One factor that could have negatively affected infection rate and lesion severity in $\mathrm{A} / \mathrm{J}$ mice dosed with $H$. marmotae is that the bacterial strain used in this study was obtained 
from an infected woodchuck and was not adapted to mice. In an earlier report, mice were allowed to self-select human strains of $H$. pylori; this resulted in mouse-adapted strains, e.g. SS1, which could efficiently colonize the stomach and induce inflammation (Lee et al., 1997). Woodchucks and mice are both members of the order Rodentiae; however, they are distinct enough from one another to be placed in different families, Scuiridae and Muridae, respectively. It is unknown whether woodchucks infected with $H$. marmotae have lower-bowel colonization and concurrent intestinal inflammation. We have recently cultured $H$. marmotae from the intestines of prairie dogs and identified it by PCR in prairie dog livers (J. G. Fox, unpublished data), thereby increasing its natural host range. To date, H. marmotae has not been cultured from wild mice.

At 6, 12 and 18 months p.i., A/J mice of both sexes dosed intraperitoneally mounted a stable IgG serological immune response to $H$. marmotae. Likewise, in an earlier study designed to examine the immune responses of male $\mathrm{A} / \mathrm{JCr}$ mice infected orally with $H$. hepaticus, essentially unchanged immunoglobulin levels were measured between 3 and 11 months after infection (Whary et al., 1998). Of interest in the present study was that serum IgG levels remained elevated at 18 months p.i. in all of the experimentally dosed mice, even in those where persistent colonization was not evident. A long-term immunological response to the bacterial antigens could be a consequence of the intraperitoneal route by which $H$. marmotae was administered. Given that H. marmotae is a Gram-negative bacterium, low-level shedding of Gram-negative enteric antigens into the portal circulation could elicit ongoing anamnestic immune responses to shared $H$. marmotae antigens. Similarly, serum IgG levels were high in Swiss Webster outbred mice dosed intraperitoneally with $H$. pylori, even though only a minority (one out of eight) of the mice was colonized with $H$. pylori 1 month after dosing. The serum titres were considerably greater than antibody titres measured in orally dosed mice (McCathey et al., 1999). In mice dosed intraperitoneally with an enteric helicobacter, the organism was not isolated from various tissues (blood, lung, spleen, liver and kidneys) 30 days p.i., but was cultured from faeces (McCathey et al., 1999). Based on these earlier findings, we also believe it is unlikely that $H$. marmotae colonized extraintestinal tissue, which could have been responsible for the sustained immune response in experimentally inoculated, but uninfected mice. Although intraperitoneal versus oral administration of Helicobacter species has been used successfully in the past (McCathey et al., 1999; Shomer et al., 2001; Ward et al., 1994), oral gavage of $H$. marmotae in subsequent experiments will clarify the immunological effects of the dosing route used.

A high prevalence of $H$. marmotae DNA has been documented in WHV-infected woodchuck livers with hepatic tumours, and WHV-negative woodchucks with $H$. marmotae infection had evidence of comparable hepatitis (Fox et al., 2002). Others have also described hepatic lesions in woodchucks seronegative for WHV (Roth et al., 1985 , 1991), although the $H$. marmotae status of the woodchucks was not established. H. marmotae in woodchucks may induce chronic inflammation that in turn promotes neoplastic changes in liver parenchyma. The present report demonstrates that $H$. marmotae can successfully colonize both the lower bowel and liver of $\mathrm{A} / \mathrm{J}$ mice, and cause substantial gastrointestinal disease. Recently, we reported that $H$. hepaticus infection promoted liver tumours in hepatitis $\mathrm{C}$ transgenic mice as well as in mice treated with aflatoxin (Fox et al., 2010). Future murine studies with a mouse-adapted $H$. marmotae will be useful for studying mechanisms of microbially induced cocarcinogenesis, and by extension the possible carcinogenic role of Helicobacter spp. in humans infected with hepatitis $\mathrm{B}$ and $\mathrm{C}$ viruses.

\section{ACKNOWLEDGEMENTS}

This work was supported by National Institutes of Health grants RO1-AI37750 and T32-RR07036. The authors thank Dr Melanie Ihrig for providing assistance with the statistical analyses.

\section{REFERENCES}

Archer, J. R., Romero, S., Ritchie, A. E., Hamacher, M. E., Steiner, B. M., Bryner, J. H. \& Schell, R. F. (1988). Characterization of an unclassified microaerophilic bacterium associated with gastroenteritis. J Clin Microbiol 26, 101-105.

Burnens, A. P., Stanley, J., Schaad, U. B. \& Nicolet, J. (1993). Novel Campylobacter-like organism resembling Helicobacter fennelliae isolated from a boy with gastroenteritis and from dogs. J Clin Microbiol 31, 1916-1917.

Cahill, R. J., Foltz, C. J., Fox, J. G., Dangler, C. A., Powrie, F. \& Schauer, D. B. (1997). Inflammatory bowel disease: an immunitymediated condition triggered by bacterial infection with Helicobacter hepaticus. Infect Immun 65, 3126-3131.

Chien, C. C., Taylor, N. S., Ge, Z., Schauer, D. B., Young, V. B. \& Fox, J. G. (2000). Identification of $c d t B$ homologues and cytolethal distending toxin activity in enterohepatic Helicobacter spp. J Med Microbiol 49, 525-534.

Cimolai, N., Gill, M. J., Jones, A., Flores, B., Stamm, W. E., Laurie, W., Madden, B. \& Shahrabadi, M. S. (1987). "Campylobacter cinaedi" bacteremia: case report and laboratory findings. J Clin Microbiol 25, 942-943.

Erdman, S. E., Poutahidis, T., Tomczak, M., Rogers, A. B., Cormier, K., Plank, B., Horwitz, B. H. \& Fox, J. G. (2003). CD ${ }^{+} \mathrm{CD}_{25}{ }^{+}$regulatory $\mathrm{T}$ lymphocytes inhibit microbially induced colon cancer in Rag2deficient mice. Am J Pathol 162, 691-702.

Erdman, S. E., Rao, V. P., Poutahidis, T., Rogers, A. B., Taylor, C. L., Jackson, E. A., Ge, Z., Lee, C. W., Schauer, D. B. \& other authors (2009). Nitric oxide and TNF- $\alpha$ trigger colonic inflammation and carcinogenesis in Helicobacter hepaticus-infected, Rag2-deficient mice. Proc Natl Acad Sci U S A 106, 1027-1032.

Fox, J. G. \& Wang, T. C. (2000). Overview of Helicobacter pylori. In Infectious Causes of Cancer: Targets for Invention, pp. 371-388. Edited by J. J. Goedert. Totowa, NJ: Humana Press.

Fox, J. G., Yan, L. L., Dewhirst, F. E., Paster, B. J., Shames, B., Murphy, J. C., Hayward, A., Belcher, J. C. \& Mendes, E. N. (1995). Helicobacter bilis sp. nov., a novel Helicobacter species isolated from 
bile, livers, and intestines of aged, inbred mice. J Clin Microbiol 33, 445-454.

Fox, J. G., Drolet, R., Higgins, R., Messier, S., Yan, L., Coleman, B. E., Paster, B. J. \& Dewhirst, F. E. (1996a). Helicobacter canis isolated from a dog liver with multifocal necrotizing hepatitis. J Clin Microbiol 34, 2479-2482.

Fox, J. G., Li, X., Yan, L., Cahill, R. J., Hurley, R., Lewis, R. \& Murphy, J. C. (1996b). Chronic proliferative hepatitis in A/JCr mice associated with persistent Helicobacter hepaticus infection: a model of helicobacterinduced carcinogenesis. Infect Immun 64, 1548-1558.

Fox, J. G., Yan, L., Shames, B., Campbell, J., Murphy, J. C. \& Li, X. (1996c). Persistent hepatitis and enterocolitis in germfree mice infected with Helicobacter hepaticus. Infect Immun 64, 3673-3681.

Fox, J. G., Dangler, C. A., Sager, W., Borkowski, R. \& Gliatto, J. M. (1997). Helicobacter mustelae-associated gastric adenocarcinoma in ferrets (Mustela putorius furo). Vet Pathol 34, 225-229.

Fox, J. G., Dewhirst, F. E., Shen, Z., Feng, Y., Taylor, N. S., Paster, B. J., Ericson, R. L., Lau, C. N., Correa, P. \& other authors (1998). Hepatic Helicobacter species identified in bile and gallbladder tissue from Chileans with chronic cholecystitis. Gastroenterology 114, 755-763.

Fox, J. G., Handt, L., Sheppard, B. J., Xu, S., Dewhirst, F. E., Motzel, S. \& Klein, H. (2001). Isolation of Helicobacter cinaedi from the colon, liver, and mesenteric lymph node of a rhesus monkey with chronic colitis and hepatitis. J Clin Microbiol 39, 1580-1585.

Fox, J. G., Shen, Z., Xu, S., Feng, Y., Dangler, C. A., Dewhirst, F. E., Paster, B. J. \& Cullen, J. M. (2002). Helicobacter marmotae sp. nov. isolated from livers of woodchucks and intestines of cats. J Clin Microbiol 40, 2513-2519.

Fox, J. G., Rogers, A. B., Whary, M. T., Taylor, N. S., Xu, S., Feng, Y. \& Keys, S. (2004). Helicobacter bilis-associated hepatitis in outbred mice. Comp Med 54, 571-577.

Fox, J. G., Shen, Z., Muthupalani, S., Rogers, A. R., Kirchain, S. M. \& Dewhirst, F. E. (2009). Chronic hepatitis, hepatic dysplasia, fibrosis, and biliary hyperplasia in hamsters naturally infected with a novel helicobacter classified in the H. bilis cluster. J Clin Microbiol 47, 36733681.

Fox, J. G., Feng, Y., Theve, E. J., Raczynski, A. R., Fiala, J. L., Doernte, A. L., Williams, M., McFaline, J. L., Essigmann, J. M. \& other authors (2010). Gut microbes define liver cancer risk in mice exposed to chemical and viral transgenic hepatocarcinogens. Gut 59, 88-97.

Garcia, A., Ihrig, M. M., Fry, R. C., Feng, Y., Xu, S., Boutin, S. R., Rogers, A. B., Muthupalani, S., Samson, L. D. \& Fox, J. G. (2008). Genetic susceptibility to chronic hepatitis is inherited codominantly in Helicobacter hepaticus-infected AB6F1 and B6AF1 hybrid male mice, and progression to hepatocellular carcinoma is linked to hepatic expression of lipogenic genes and immune function-associated networks. Infect Immun 76, 1866-1876.

Hailey, J. R., Haseman, J. K., Bucher, J. R., Radovsky, A. E., Malarkey, D. E., Miller, R. T., Nyska, A. \& Maronpot, R. R. (1998). Impact of Helicobacter hepaticus infection in $\mathrm{B} 6 \mathrm{C} 3 \mathrm{~F} 1$ mice from twelve National Toxicology Program two-year carcinogenesis studies. Toxicol Pathol 26, 602-611.

Ihrig, M., Schrenzel, M. D. \& Fox, J. G. (1999). Differential susceptibility to hepatic inflammation and proliferation in AXB recombinant inbred mice chronically infected with Helicobacter hepaticus. Am J Pathol 155, 571-582.

Kirkbride, C. A., Gates, C. E., Collins, J. E. \& Ritchie, A. E. (1985). Ovine abortion associated with an anaerobic bacterium. J Am Vet Med Assoc 186, 789-791.

Lee, A., O'Rourke, J., De Ungria, M. C., Robertson, B., Daskalopoulos, G. \& Dixon, M. F. (1997). A standardized mouse model of Helicobacter pylori infection: introducing the Sydney strain. Gastroenterology 112, 1386-1397.

Li, X., Fox, J. G., Whary, M. T., Yan, L., Shames, B. \& Zhao, Z. (1998). SCID/NCr mice naturally infected with Helicobacter hepaticus develop progressive hepatitis, proliferative typhlitis, and colitis. Infect Immun 66, 5477-5484.

McCathey, S. N., Shomer, N. H., Schrenzel, M. D., Whary, M. T., Taylor, N. S. \& Fox, J. G. (1999). Colonization and tissue tropism of Helicobacter pylori and a novel urease-negative Helicobacter species in ICR mice are independent of route of exposure. Helicobacter 4, 249-259.

Menne, S. \& Cote, P. J. (2007). The woodchuck as an animal model for pathogenesis and therapy of chronic hepatitis B virus infection. World J Gastroenterol 13, 104-124.

Orlicek, S. L., Welch, D. F. \& Kuhls, T. L. (1993). Septicemia and meningitis caused by Helicobacter cinaedi in a neonate. J Clin Microbiol 31, 569-571.

Roth, L., King, J. M., Hornbuckle, W. E., Harvey, H. J. \& Tennant, B. C. (1985). Chronic hepatitis and hepatocellular carcinoma associated with persistent woodchuck hepatitis virus infection. Vet Pathol 22, 338-343.

Roth, L., King, J. M. \& Tennant, B. C. (1991). Hepatic lesions in woodchucks (Marmota monax) seronegative for woodchuck hepatitis virus. J Wildl Dis 27, 281-287.

Shen, Z., Feng, Y., Rogers, A. B., Rickman, B., Whary, M. T., Xu, S., Clapp, K. M., Boutin, S. R. \& Fox, J. G. (2009). Cytolethal distending toxin promotes Helicobacter cinaedi-associated typhlocolitis in interleukin-10-deficient mice. Infect Immun 77, 2508-2516.

Shomer, N. H., Dangler, C. A., Schrenzel, M. D., Whary, M. T., Xu, S., Feng, Y., Paster, B. J., Dewhirst, F. E. \& Fox, J. G. (2001). Cholangiohepatitis and inflammatory bowel disease induced by a novel urease-negative Helicobacter species in A/J and Tac:ICR:Hascidf RF mice. Exp Biol Med (Maywood) 226, 420-428.

Sundberg, J. P., Fox, J. G., Ward, J. M. \& Bedigian, H. G. (1997). Idiopathic focal hepatic necrosis in inbred laboratory mice. In Digestive System, 2nd edn, pp. 213-217. Edited by T. C. Jones, J. A. Popp \& V. Mohr. New York: Springer.

Tennant, B. C. \& Gerin, J. L. (2001). The woodchuck model of hepatitis B virus infection. ILAR J 42, 89-102.

Vandamme, P., Falsen, E., Pot, B., Kersters, K. \& De Ley, J. (1990). Identification of Campylobacter cinaedi isolated from blood and feces of children and adult females. J Clin Microbiol 28, 1016-1020.

Ward, J. M., Fox, J. G., Anver, M. R., Haines, D. C., George, C. V., Collins, M. J., Jr, Gorelick, P. L., Nagashima, K., Gonda, M. A. \& other authors (1994). Chronic active hepatitis and associated liver tumors in mice caused by a persistent bacterial infection with a novel Helicobacter species. J Natl Cancer Inst 86, 1222-1227.

Ward, J. M., Anver, M. R., Haines, D. C., Melhorn, J. M., Gorelick, P., Yan, L. \& Fox, J. G. (1996). Inflammatory large bowel disease in immunodeficient mice naturally infected with Helicobacter hepaticus. Lab Anim Sci 46, 15-20.

Weir, S., Cuccherini, B., Whitney, A. M., Ray, M. L., MacGregor, J. P., Steigerwalt, A., Daneshvar, M. I., Weyant, R., Wray, B. \& other authors (1999). Recurrent bacteremia caused by a "Flexispira"-like organism in a patient with X-linked (Bruton's) agammaglobulinemia. J Clin Microbiol 37, 2439-2445.

Whary, M. T., Morgan, T. J., Dangler, C. A., Gaudes, K. J., Taylor, N. S. \& Fox, J. G. (1998). Chronic active hepatitis induced by Helicobacter hepaticus in the A/JCr mouse is associated with a Th1 cell-mediated immune response. Infect Immun 66, 3142-3148.

Young, V. B., Knox, K. A., Pratt, J. S., Cortez, J. S., Mansfield, L. S., Rogers, A. B., Fox, J. G. \& Schauer, D. B. (2004). In vitro and in vivo characterization of Helicobacter hepaticus cytolethal distending toxin mutants. Infect Immun 72, 2521-2527. 